\title{
Exploration of Wood Waste Materials for Fashion Products
}

\author{
Nina Maftukha ${ }^{1 *}$ Shinta Malasari ${ }^{2}$ Nurulahda binti Sulaiman ${ }^{3}$ \\ 1. Product Design, Universitas Mercu Buana Jakarta, PO box 11650, Jl. Meruya Selatan No. 1, \\ Kembangan, West Jakarta, Indonesia \\ 2. Universitas Mercu Buana Jakarta, Jl. Meruya Selatan No. 1, Kembangan, West Jakarta,11650.Indonesia \\ 3. Faculty of Creative Technology and Heritage, Universiti Malayasia Kelantan \\ * E-mail of the corresponding author: nina.maftukha@mercubuana.ac.id
}

\begin{abstract}
Industrial and domestic production processes generally result in the disposal or what we know as waste. Based on the activities carried out, wood waste consists of several types and characteristics. The kind of wood waste used is sawdust. Therefore, the author raises the theme of exploration of wood waste into new materials for fashion products. This study aims to increase the functional and economic value of wood sawdust into a new material that has high economic value.

In this study, the authors explored wood waste into new materials for fashion products using the assembly method. The raft design technique used is the non-woven technique. This technique has processes such as being compressed, heated, bonded, and chemically so that it can become new material. The resulting material is a material that resembles cowhide.
\end{abstract}

Key words: exploration, wood waste, material, fashion, products.

Publication date:September $30^{\text {th }} 2020$

DOI: $10.7176 / \mathrm{ADS} / 85-06$

\section{Introduction}

wood is one of the building materials that has long been known by the community and is a material that is very often used, including as building construction materials, which function as structures and non-building structures. in indonesia, there are many types of wood from the number of tree species produced as a result that have different traits. each type of plant has wood products that have different properties (wood), so that in the selection or determination of species for the purpose of use in accordance with what is desired, whether for construction (structure), whether it is used as furniture or as material for non-structural art needs.

wood waste comes from the remaining pieces of trees or the remaining wood produced. wood from waste produced by the production process is also called waste. wood has the benefits to the smallest size and has great potential to be utilized or processed into various products. the utilization of wood waste in the market has begun to emerge. however, due to the increasing amount of wood waste every day it continues to become a waste.

utilization of wood waste can also be one way to reduce waste in the environment and can reduce production costs in making a product. especially in wood workshops, wood powder and the remaining pieces of wood are rarely used even just thrown away or often given free of charge to people who ask for powder and leftover pieces of wood. seeing the opportunity to easily get raw material for wood waste, the author is interested in wood waste to be used as new textile material so that it can be utilized in making a product.

in this study, the authors explored wood waste into new material for fashion products with their assembled methods. the raft method to be used is a non-woven technique. this technique has processes such as solidified, heated, glued and chemical so that it can become new material.

\section{Research Methodology}

\subsection{Type of Investigation}

This research will be conducted using the experimental method. The experimental method used in exploring wood powder waste refers to the Research and Development (R \& D) method, with an explorative approach. 


\section{$2.2 \quad$ Research Process}

The research process is generally divided into two stages, namely data collection and data analysis. , starting from choosing suitable wood powder, adhesives and matching binders, and methods for applying color (by coloring, heating and arranging patterns according to the color of the wood powder), processing natural dyes to obtain dyes, applying raft engineering in wood powder waste. During the process, several stages of observation and analysis are carried out to select the effects of each method and choose the ideal method.

\subsection{Data Collection}

Data collection is done to collect data related to the topic, which are divided into two main categories:

a.Primary data are collected directly through experiments. There are several stages in the experiment:

1)Stage 1: Exploring the latex dose, wood powder waste

2)Stage 2: Applying the dosage to the material

3)Step 3: The gluing process

4)Stage 4: the printing and drying process.

Research variables at each stage are listed as follows:

1)Stage 1: dose of material exploration tested

2)Phase 2: the application of exploration for wood powder, latex, and fabric

Secondary sources Secondary data is collected through a literature review.

\subsection{Data Analysis Techniques}

Data analysis techniques used are analytical techniques with experimental approaches. after that, the experimental results data will be compiled, classified, then analyzed. the stages finally determine the best experimental results from the eleven experiments that have been tested.

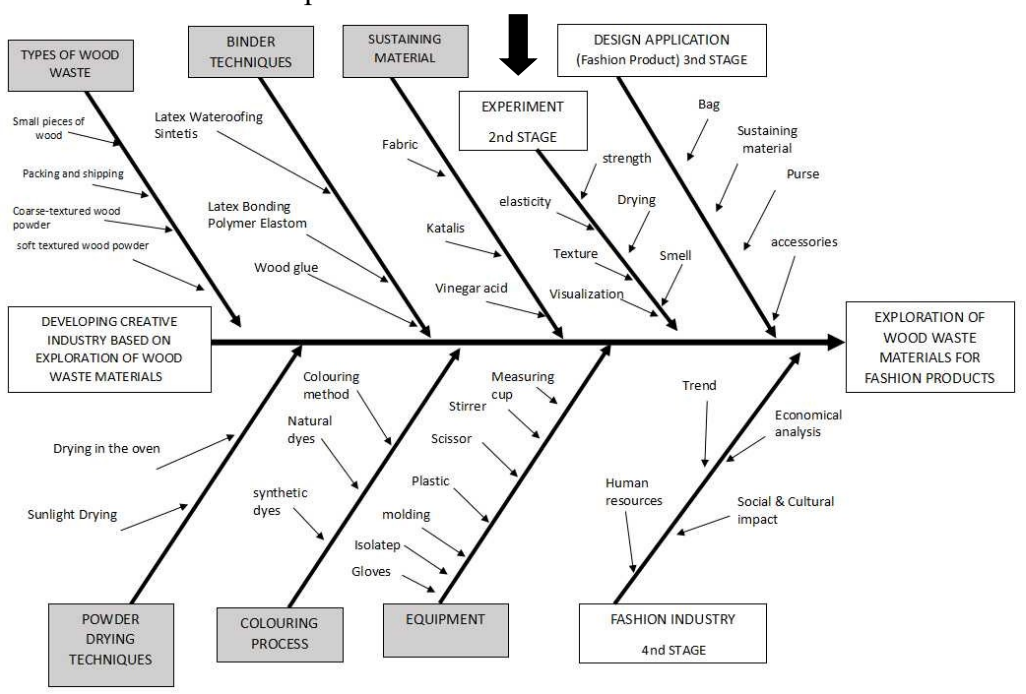

Figure1. Data Analysis Process

Information:

1st STAGE

2nd STAGE

The analysis was carried out on the results of previous trials. At this stage, all test results compare to determine the exploration of suitable materials and methods of research on wood waste treatment for fashion products. Analysis of each click on:

Stage 1: the process of selecting wood waste material a.wood drying process, drying method, and type dryer b.the process of selecting adhesive materials, gluing methods, and the type of adhesive c.coloring process (coloring method and results)

Stage 2: material exploration process (level of elasticity, texture, drying, strength, odor, and visual. 


\section{Result and Discussion}

Exploration of Wood Waste Materials for Fashion Products uses non-woven fabric assembly techniques. Nonwoven fabric assembling techniques are techniques which are compacted, heated, glued and used in the experiment of new materials. The new material produced will be used as the basic material for fashion products.

\subsection{Wood Sawdust Waste}

There are 4 types of wood sawdust waste in CV Mekar Budi, which are as follows:

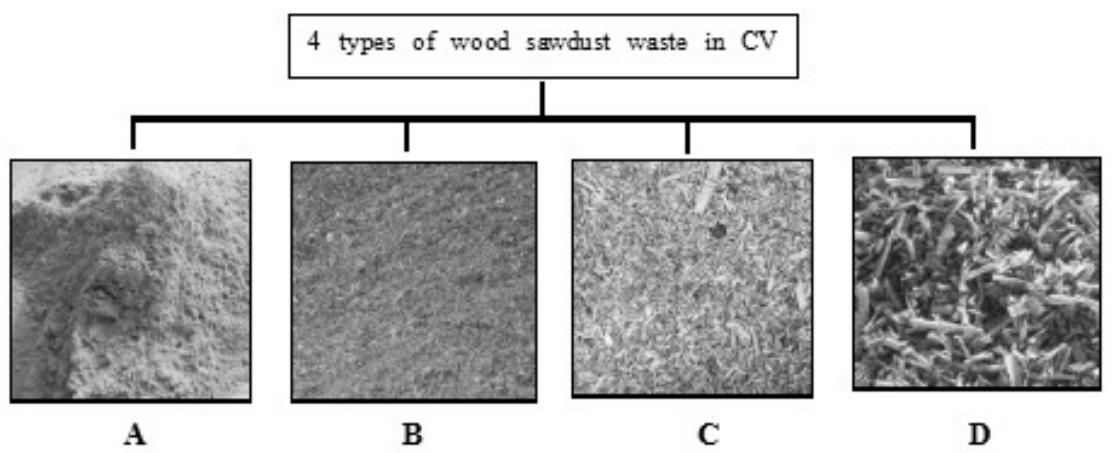

Figure 2. Documentation of fine sawdust from mowers Source: Author, 2018

Caption:

-Fine Wood Powder A and B: Fine wood powder produced from the remaining wood cutting work by machines in the form of fine wood powder (A) and fine wood powder (B).

-Coarse Wood Removal A: Coarse wood waste resulting from the refinement process in the form of small pieces of wood lasts about $0.5 \mathrm{Cm}$

-Coarse wood residue B: Coarse wood waste resulting from the refinement process in the form of small pieces of wood extending around $1 \mathrm{Cm}$

This experimental study uses fine wood powders A and B to see and explore the tensile strength and strength of waste materials. The fine powders A and B have very dense types of particles, so they are very supportive of new material strengths.

\subsection{Experimental supporting tools and materials}

The following are the equipment that must provide during the experiment.

1) A pan for drying wood sawdust

2) Pot for the chemical coloring process

3) Oven for drying wood sawdust

4) Spatula to stir in the drying process of sawdust

5) A container for draining and drying the coloring results

6) Jars for coloring containers that are ready to use

7) Gas stoves for wood drying and coloring processes

8) Plastic cups for the mixing process of sawdust with adhesives

9) Plastic spoon for stirring the adhesive paste with sawdust

10) Scissors to cut cloth

11) Isolative for the printing process

12) Filter for classifying the size of sawdust

The following equipment must be doing provided at the time of the experiment: 
1) Latex Synthetic Waterproofing as an adhesive

2) Croton cloth as a binder

3) The catalyst as a binding agent

4) Vinegar to eliminate odors

5) Water for the coloring process uses textile dyes

6) Textile dyes for wood powder dyes

\subsection{Wood Powder Drying Techniques}

\subsubsection{Sun Drying}

The process of drying with sunlight is very dependent on the weather. In this stage, it takes more or less a week for the drying process. After drying, the wood powder is slightly brownish.

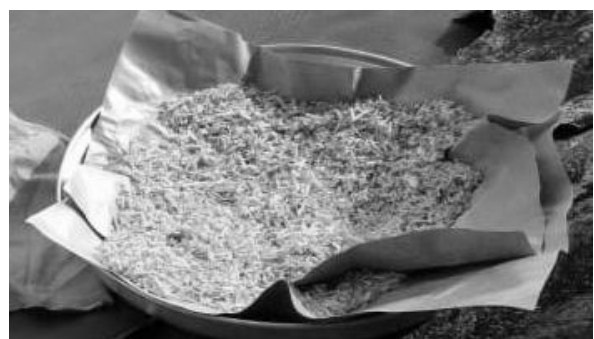

Figure 3. The process of drying with sunlight Source: Author, 2019

\subsubsection{Drying in the Oven}

The drying process using an oven takes 1 hour. Occasionally it needs to be stirred to dry evenly.

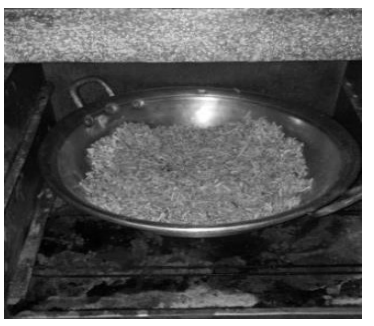

Figure 4. Documentation of oven drying results Source: Author, 2019

\subsection{Coloring Process}

The coloring process uses two coloring techniques are using textile dyes and naturally.

3.4.1 Textile dyes

The following are the steps in conducting an experiment using textile dyes:

a) Cook $1000 \mathrm{ml}$ of water until it boils

b) Enter textile dyes

c) Put the sawdust and stir until blended for up to 60 minutes

d) Dry in the sun to dry. 


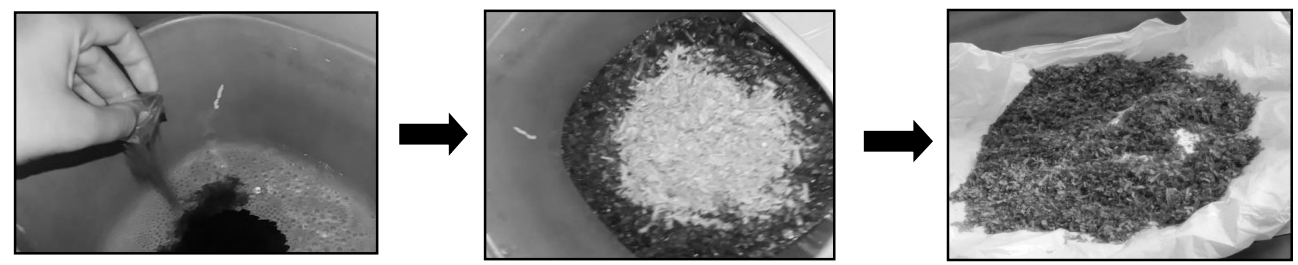

Figure5. The process of staining and drying wood dust with textile dyes Source: author, 2019

\subsubsection{Natural dyes}

Coloring naturally uses a frying pan by roasting, but some things need to notice when sawdust.

a)Stirring is continuously so that the results to evenly distributed.

b)The longer roasted more concentrated the color obtained.

c)The color obtained is only light brown to black.

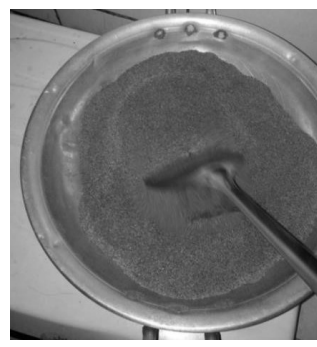

Figure 6. Wood sawdust process Source: Author, 2019

From the two stages of wood sawdust coloring techniques, it can conclude that there are several advantages and disadvantages as below.

Table1. Conclusion Wooden powder coloring techniques.

\begin{tabular}{|c|c|c|}
\hline No & Textile dyeing techniques & Natural dyeing techniques \\
\hline 1 & Varied colors. & Light brown, dark brown and black \\
\hline 2. & Must be dried and dried & No need to sunbathe \\
\hline
\end{tabular}

Source: Author, 2019

Both of these techniques can be applied to fashion products as needed.

\subsection{Molding Technic}

The exploration process of wood waste material assemblies uses molds, LWP latex adhesives, plastics, rollers, scissors, and isolates.

\subsection{Exploration Of Wood Waste Material For Fashion Products}

\subsubsection{Eksperiment 1}

Ingredients: $40 \mathrm{ml}$ fine wood powder, $120 \mathrm{ml}$ LWP latex, $10 \mathrm{ml}$ vinegar.

Creation level:

- Mix LWP latex, vinegar, and the fine wood powder

- Pour into the mold provided with a cloth base

- Sunset in the sun 
Experiment Results:

- Trial Status: Success

- Drying Time: 3 (three) days

- Strength: Strong and elastic

- Visualization: Resembling cow skin

- Weaknesses: Smells vinegar acid

- Texture: Slightly sticky on the top surface.

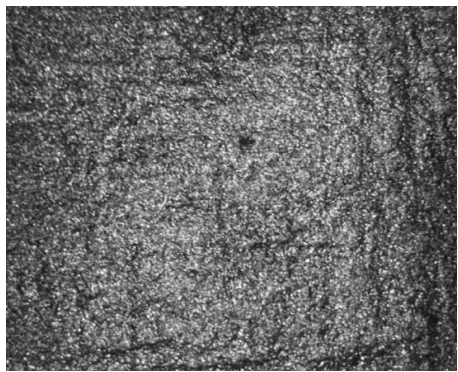

Figure7. Documentation of the first experiment 1 Source: Author, 2019

\subsubsection{Eksperiment 2}

Ingredients: $40 \mathrm{ml}$ fine wood powder, $100 \mathrm{ml}$ lwp latex, 1 drop vinegar

creation level:

- mix lwp latex, vinegar, and fine wood powder

- pour into the fabric of the cloth

- sunset in the sun.

Experiment Results:

- Trial Status: Success

- Drying Time: 3 (three) days

- Strength: Strong and elastic

- Visualization: Resembling cow skin

- Weaknesses: Smells vinegar acid

- Texture: Slightly sticky on the top surface.

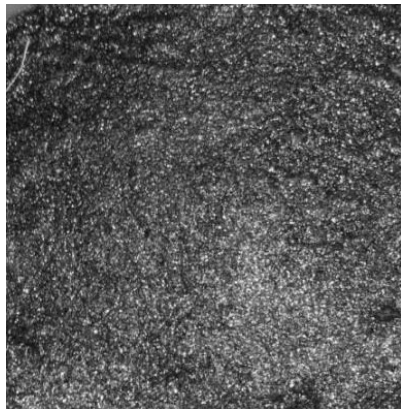

Figure8. Documentation of the results of the experiment 2 Source: Author, 2019

3.6.3 Eksperiment 3

Ingredients: $50 \mathrm{ml}$ fine wood powder, Lateks LWP $90 \mathrm{ml}, 1$ drop vinegar 
Creation level:

-Mix LWP Latex, vinegar acid, and fine wood powder

-Pour into the mold that has to be cover with a cloth

-Dry in the sun

Experiment Results:

-Trial Status: Success

-Drying Time: 2 (two) days

-Strength: Strong and very elastic

-Visualization: Resembling cow skin

-Weaknesses: The upper side smells of vinegar

-Texture: The texture of the top is a little rough

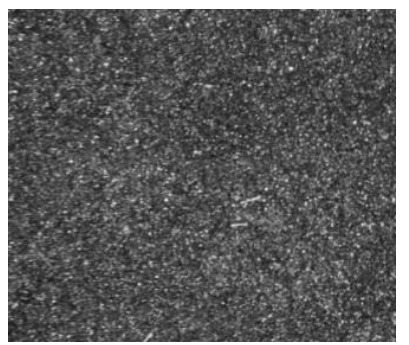

Figure 9. Documentation of the results of the experiment 3 Source: Author, 2019

\subsubsection{Eksperiment 4}

Ingredients: Latex LWP $100 \mathrm{ml}$, Fine Wood Powder $60 \mathrm{ml}$

Creation level:

- Mix LWP Latex and sawdust, stir until evenly distributed

- Once evenly distributed, roll over the mold, specifically for the mold in this experiment using an infra board without a plastic or cloth base.

- After being thinly ground, brush the latex to the surface of the mixture.

- Dry in the sun

Experiment Results:

- Trial Status: Success

- Drying Time: 2 (two days)

- Strength: stronger with a thinner size than experiments 1,2 , and 3.

- Level of elasticity: can be bent.

- Texture: Smooth and odorless

- Visualization: soft and smooth

- Weaknesses: very difficult to remove from the mold

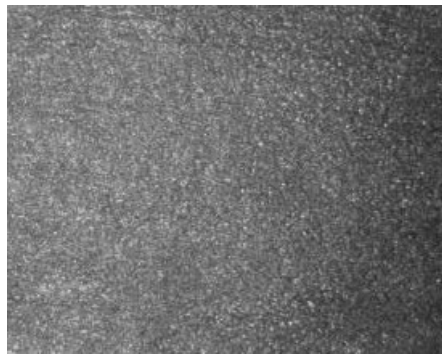

Figure10. Documentation of the results of the experiment 3 Source: Author, 2019 


\subsubsection{Eksperiment 5}

Ingredientsl: $100 \mathrm{ml}$ LWP Latex, $60 \mathrm{ml}$ Fine Wood

Creation level:

-Mix LWP Latex and sawdust, stir until evenly distributed

-Once evenly distributed, roll over the mold, specifically for the mold in this experiment using an infra board without a plastic or cloth base.

-After being thinly ground, brush the latex to the surface of the mixture.

-Dry in the sun

Experiment Results:

-Trial Status: Success

-Drying Time: 3 (three days)

-Strength: Very strong, elastic, bendable

-Texture: Smooth

-Visualization: Thin, smooth, resembling cowhide, odorless

-Deficiency : :

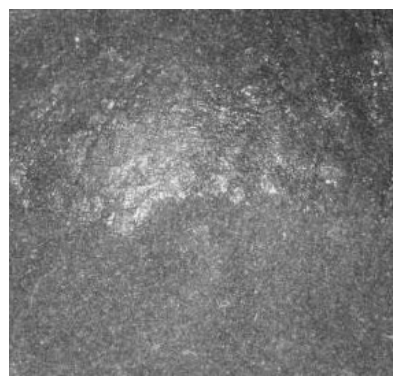

Figure11. The results of the experiment 5.Source: Author, 2019

\subsubsection{Eksperiment 6}

Ingredients: $100 \mathrm{ml}$ LWP Latex, $60 \mathrm{ml}$ Fine Wood Powder, and Fabric

Creation level:

-Mix LWP latex and sawdust, stir until evenly distributed

-LWP coated latex cloth using a brush

-After evenly distributed, rollover a mold that has covered with the fabric experiment uses board, then is rolled, and coated with plastic using a glass.

-After being thinly rolled back, give LWP latex using a brush on the surface of the dough.

-Dry in the sun

Experiment Results:

-Trial Status $\quad$ : Success

-Drying Time : : 3 (three days)

-Strength

: Very strong, can be bent back and forth

-Texture

: Smoother, and thinner than experiment 5

-Visualization

: Smooth, brown like cow skin, odorless

-Deficiency 


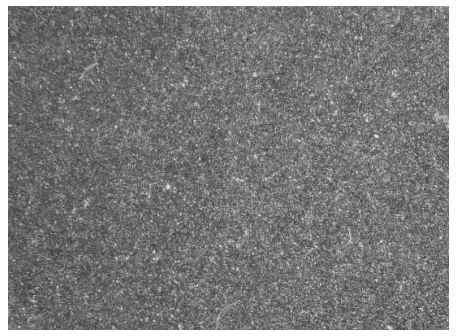

Figure 12. Documentation of the results of the experiment 6. Source: Author, 2019

\subsubsection{Conclusion of Experiment Results}

The results of the six experiments were the most successful, namely, the 5th and 6th experiments. The presentation is as follows:

Table 3.2 Table of differences between result experiment 5 and 6

\begin{tabular}{|c|c|c|c|}
\hline No & Information & Experiment 5 & Experiment 6 \\
\hline 1 & Trial Status & success & success \\
\hline 2 & Drying Time & 3 (three days) & 3 (three days) \\
\hline 3 & Strength & Very strong & Very strong \\
\hline 4 & $\begin{array}{l}\text { Level of } \\
\text { Elasticity }\end{array}$ & elastic, bendable & $\begin{array}{l}\text { Very strong, can be bent back } \\
\text { and forth }\end{array}$ \\
\hline 5 & Visualization & $\begin{array}{l}\text { Thin, smooth, resembling } \\
\text { cowhide, shiny }\end{array}$ & 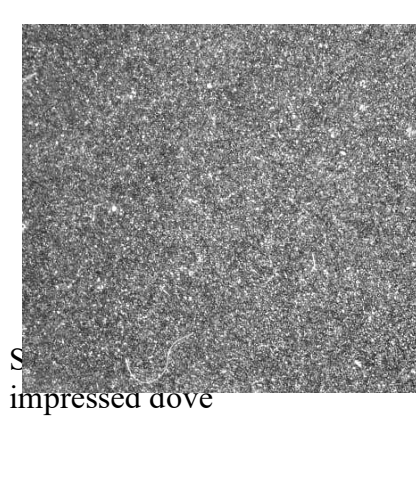 \\
\hline 6 & Texture & Smooth & $\begin{array}{l}\text { Smoother, and thinner than } \\
\text { experiment } 5\end{array}$ \\
\hline 7 & Smell & No smell & No smell \\
\hline 8 & Deficiency & - & - \\
\hline
\end{tabular}




\section{Conclusion and Suggestion}

\subsection{Conclusion}

In the research "exploration of wood waste materials for fashion products, " the authors conducted 6 (six) experiments. The main ingredients use fine wood powder, mixing materials using Latex Synthetic Waterproofing, binder using cloth, and vinegar.

The first experiment consisted of a composition of $40 \mathrm{ml}$ fine wood powder, $120 \mathrm{ml}$ LWP latex, $10 \mathrm{ml}$ vinegar. The experiments took place in three days, experimental results have been successful, the material is strong and elastic, the material visualized resembling cowhide with a slightly sticky texture on the top surface, the weakness smelled of vinegar.

The second experiment consisted of a composition of $40 \mathrm{ml}$ of fine wood powder, $100 \mathrm{ml}$ of latex LWP, one drop of vinegar. The experimental period of three days, experimental results have been successful, the material is strong and elastic, the material visualized resembling cowhide with a slightly sticky texture on the top surface, the weakness was a little sour vinegar.

The third experiment consisted of a composition of $50 \mathrm{ml}$ of fine wood powder, $90 \mathrm{ml}$ of LWP latex, one drop of vinegar. The experimental period of two days. Experimental results have been successful. The material is strong and very elastic. The material has a visualization resembling cowhide with a rough texture on the top surface. The disadvantage of the material is that it has a vinegar smell.

The fourth experiment consisted of $100 \mathrm{ml}$ LWP latex composition, $60 \mathrm{ml}$ fine wood powder. The experimental period of two days, the trial status was successful, the material is strong, the size is thinner than experiments 1,2 , and 3 , the material is elastic and can be bent, has a visualization resembling cowhide, smooth texture, and odourless.

The fifth experiment consisted of a composition of $100 \mathrm{ml}$ of LWP latex and $60 \mathrm{ml}$ of Fine Wood. The experimental period of three days, the trial status was successful, the material is strong and more elastic compared to experiments $1-4$, the visualization of the material resembled cowhide with a smooth texture and thinner, odourless.

The sixth experiment consisted of a composition of $100 \mathrm{ml}$ of LWP latex, $60 \mathrm{ml}$ of fine wood powder, and cloth. The experimental period of three days, the trial status was successful, the material is stronger and more elastic compared to experiments $1-5$, the visualization of the brown material resembled cowhide, the texture was smooth and thinner than the fifth experiment, odourless.

The first to fourth attempts were successful, but had a vinegary smell, leaving marks when bent and folded. The fifth to sixth experiments had satisfactory results. The visualization of the material resembled cowhide with a very smooth texture, very strong and elastic, odourless, and had met the standards for being used as a fashion product material.

To produce a good material, try not to use vinegar, as it can cause an unpleasant odour. The binder material should not use a catalyst, because the resulting material will not be elastic and will leave marks when the material is folded.

\subsection{Suggestion}

The thing that needs to be improved is in terms of visualizations. This matter can explore in the process of color and motif combination. Roll material can be innovated in shape to produce thinner and material strength.

\subsection{Acknowledgement}

The author would like to thank the Mercu Buana University Research Institute and all who have helped in the research process.

\section{References}

Andriani Woro dkk. (2018).Evaluasi Jenis Bahan Penstabil dan Koagulan Lateks Pada Sistem Reaksi Hidrogenasin Katalitik Lateks Karet Alam Skala Semi Pilot.

Goet, Poespo. (2005). Pemilihan Bahan Tekstil. Yogyakarta: Kanisius.

Ismuyanto, Bambang. (2017). Teknik Pengolahan Limbah Padat. Malang: UB Media Universitas Brawijaya.

Listyanto, Tomy. (2016). Teknologi Pengeringan Kayu dan Aplikasinya. Yogyakarta: Gadjah Mada University Press. 
M. Damanik, Revandi Iskandar. (2003). Keawetan Kayu. Program Studi Ilmu Kehutanan Falkultas Pertanian Universitas Sumatera Utara.

Maryanti dkk. (2016). Pengaruh Dosis Serum Lateks terhadap Koagulasi Lateks (Havea brasiliensis). Jurnal Agro Industri Perkebunan.

Riadi, Muchlisin. (2013). Limbah Kayu. (Internet). Tersedia di: https://www.kajianpustaka.com/2013/03/limbahkayu.html.

Rumeksa N, Petrianika. (2012). Eksplorasi Serat Kapuk (Ceiba Pentandra) Dengan Teknik Tenun ATBM dan Kempa. Jurnal Tingkat Sarjana Bidang Senirupa dan Desain.

Suhaya, Yoyo. (2017). Stabilisasi Dimensi Pada Produk Kayu Melalui Pengeringan Konvensional. Laporan Penelitian Dosen Muda.

Sutarman, Wayan. (2016). Pemanfaatan Limbah IndustriPengolahan Kayu di Kota Denpasar. Program Studi Teknik Industri Universitas Mabendrata Denpasar.

Yuli Yanto, Dede Heri dkk. (2006) Campuran Lateks Alam Stirena dan Poliisosianat Sebagai Perekat Kayu Lamina. UPT Balai Litbang Biomaterial Lembaga Ilmu Pengetahuan Indonesia. 